Richard ; the Albert lst of Monaco prize to A. Cotton for the continuation of his researches on powerful magnetic fields.

Special Foundations. - The Lannelongue foundation between Mmes. Cusco and Rück; the HelbronnerFould prize to Mme. Marcel Bertrand for assisting the publication of the collected researches of the late M. Bertrand.

Prizes of the Grandes Écoles.-The Laplace prize to Pierre Robert ; the L. E. Rivot prize between Pierre Robert, Alphonse Grange, Roger Dodu, and Marcel Davin.

Foundations for Scientific Research.-The Trémont foundation to André Charrueau for his researches on the equilibria of fluids; the Gegner foundation to Maurice Vèzes for his treatise on physical chemistry; the Jérome Ponti foundation to Pierre Cappe de Baillon for his researches on the teratology of insects ; the Hirn foundation to Maurice Gevrey for his work on partial differential equations; the Henri Becquerel foundation to Paul Lévy for his works on functional analysis.

\section{The Loutreuix Foundation.}

The Academy received 31 requests for grants from this foundation, 25 of which were acceded to as follows:

National Museum of Natural History, 11,000 francs for the establishment of a catalogue of the books in the laboratory libraries : 12,000 francs to the École Polytechnique for the use of the library; 2000 francs to M. Nicolas, director of the National Veterinary School of Alfort, for his biochemical researches on thiourea and its derivatives; 4000 francs to M. Maignon for continuing his researches, especially on the influence of the seasons and of the genital glands on basal metabolism and the specific dynamic action of foods in the dog; 4000 francs to the National Veterinary School of Lyons for the completion of sets of foreign periodicals in the library ; 4000 francs to the National Veterinary School of Toulouse for additions to its library ; 4000 francs to the National Agronomic Institute for the completion of sets of periodicals in its library interrupted by the War ; 3000 francs to Paul Nottin for his researches on the saccharification of starch.

Conservatoire national des Arts et Métiers.-5000 francs to Léon Guillet for the purchase of material for researches on the action of repeated stresses on metals and for the development of installations for thermal treatment ; $\mathbf{4 0 0 0}$ francs to the library for the purchase of books.
Grants other than to Institutions. - 5000 francs to René Jeannel for the publication of parts 57 to 59 of the zoological studies undertaken on material collected in the course of the expedition made by him (with $\mathbf{M}$. Alluaud) in Central Africa ; 5000 francs to Louis Bazy for his researches on the curative and preventative properties of the bacillus of paratuberculous enteritis of cattle and of its extracts; 5000 francs to Mme. Delage as the last contribution to the publication of the last volume of the biological annual ; 1000 franes to Édouard Doublet for the publication of a historical work on Gustave Lambert ; 2000 francs to Henri Douvillé for the research in the field of fossils permitting the completion of the study of the Rudist limestones of the Pyrenees; 5000 francs to the "Faune des Colonies françaises"; 2000 francs to Gaston Fayet to ensure the regular publication of the Bulletin of the Nice Observatory ; 5000 francs for the publication of material collected by the cruises of the Travailleur and the Talisman; 6000 francs to Henri Humbert to contribute to his studies of the flora of the high mountains of Madagascar and its comparison with that of tropical Africa; 3000 francs to the Institut d'Optique for the purchase of books to complete its library ; 8000 francs to Jean Mascart to contribute towards the cost of printing observations of work carried out or centralised at Lyons ; 5000 francs to the Paris Observatory for completing the publication of Lalande's catalogue ; 8000 francs to the Zo-Se Observatory to assist in the publication of observations made at this Observatory; 4000 francs to Jean Piveteau to undertake geological and palæontological researches in southern Tunis; 8000 francs to $J$. Risbec for the purchase of apparatus to enable him to carry on his biological researches in New Caledonia.

The Mme. Victor Noury foundation between Fernand Blondel (4000 francs) for his work on the geology of Indo-China, René Fortrat ( 3000 franes) for his work on spectroscopy, and Lucien Klotz (30,00 franes) for his work in connexion with the rights of authors and scientific men and the protection of scientific property ; the Bouchard foundation to Constantin Toumanoff for the continuation of his researches on the normal and pathological (microbial diseases) physiology of insects ; the Ray-Vaucouloux foundation to Claudius Regaud for the whole of his work on the action of radium and of the $\mathrm{X}$-rays on normal and on pathological tissues, with special reference to the use of the radiations in the treatment of various cancerous growths.

\title{
Annual Meeting of the Mathematical Association.
}

"WHERE you find a low standard of education, there you find with it dark superstition and enslavement to formulæ in every aspect of life." No reader of NATURE is likely to quarrel with this statement (liberally misquoted from memory) with which Mr. N. J. Chignell began his paper on "The Use and Abuse of Formulæ" at the annual meeting of the Mathematical Association on Jan. 7 and 8. Happiest among his examples of the general formulæ that are being questioned by a world awaking to thought, before he came to those which belong distinctively to mathematies or science, was this: "That a cloth cap must always be taken off in the presence of a top-hat." Not many years ago, the ensuing discussion would certainly have brought to light some of our dear old friends with their final argument that "memorising formulæ gets boys through who are too stupid to pass in any other way." These are not extinct ; but "the sun ariseth and they get them away together, and lay them down in their dens." Even the examiner, formerly the arch-enemy, looks now for understanding rather than memory, so Prof. Neville told us : there is much that the examiner can do to help, by forbidding the use of unproved formulæ or by setting a question to which no 'crammable' formulæ apply.

One of the quaintest of our modern superstitions is that the common methods of voting give us the representatives we want. A singularly interesting paper by Prof. J. E. A. Steggall, illustrated by numerous examples from his own experience at Dundee, showed how remarkably effective they can be in giving us just those representatives whom the majority decidedly prefer to do without. When two prizes for valour were to be awarded after the battle of Salamis, it is recorded that the commander of the contingent from every Greek state modestly recommended himself for the first prize and Themistocles for the second : the system of counting first places only would have left the greatest soldier of his time at the foot of the poll. Nearer home than that, it is no uncommon thing for $A$ to be elected out of three candidates on 
'first-choice' votes alone, when actually a majority prefers $B$ to $A$, and at the same time $C$ is also preferred to $A$ by a majority of the voters. The impact of mathematical thought upon human affairs lags far behind the work of chemistry, electricity and psychology in making a world for man to live in : this matter of elections of various kinds is conspicuously one in which the mathematician should feel his responsibility for making to the national thought that contribution for which his gifts and training fit him.

Proportional representation, a plan lying outside the limits which time set to Prof. Steggall's discussion, deserves from mathematicians (and other's) far more notice than it has yet received; but this is distinctively a method of electing two or more : it has nothing to tell us about the best way to pick out from a number of candidates the one who is preferred to the others individually by the largest majorities of the voters. If twenty such candidates compete for one place, we should regard the contest as 190 duels between one candidate and another : it is surprisingly easy, both for voter and for counter, so to arrange the election that the algebraic sum of every candidate's majorities in his 19 contests emerges directly from a single ballot.

It is safe to forecast that for some centuries to come "Modern Mathematical Problems in Aerodynamics" will be a fruitful meeting-ground for science and mathematics. Prof. H. Levy's researches into the vortex motion set up in the air by the passage through it of an aeroplane's wing deserves something better than the comments of one ignorant of aerodynamics : therefore let it pass unsung, but not unhonoured.

"Should a candidate for School Certificate be allowed to take, in place of the Mathematics and Science Group, a Group containing Drawing and Music and possibly other subjects?" This was the principal subject for general discussion-a somewhat one-sided discussion, because, though on details there was as much divergence of opinion as one would expect, there was but little opposition to the general principle involved, that children well gifted and well taught in subjects of three different kinds should not be classified as educational failures because of weakness in a fourth. Music, drawing, and handicraft constitute a group at present generally inferior for certificatewinning purposes to the other three, which are English subjects, languages, and the science-mathematics group.

This arrangement finds few defenders : some of its opponents are for republican equality between all groups, others for supremacy of one only, the English group. A powerful advocate of this supremacy was Mr. F. H. Knight, who boldly claimed for English subjects the place of honour as most of all a means of access to 'the things of the spirit,' without which other learning will not save the world. Mr. Knight also stressed the educational value of handicraft, not only as being for many children the only form in which solid geometry can be digested, but also for its influence on the development of mind on a wider scale than the mere book-learner can ever appreciate.

Science and mathematics are strong enough to stand on their own merits without needing to entrench their position by decrying the value of other subjects. Generosity, justice, and common sense would alike have been outraged if the Mathematical Association had denied that to the artist his subject is of no less value than is ours to us. Best of all, Demetrius the silversmith was conspicuous by his absence, "which made silver shrines for Diana," and whose trump-card against a rival to his goddess was that "by this craft we have our wealth.", W. HOPE-JoNes.

\section{The Circulation of Seismological Information by Wireless Telegraphy.}

$\mathrm{T}$ a recent issue of NATURE (Dec. 22, p. 968) a short account was given of the existing arrangements for broadcasting early information concerning important earthquakes, and it was announced that the co-operation of American seismological stations would commence this month.

The large earthquake which occurred on Jan. 13 afforded an interesting test of the scheme, and it is satisfactory to record that data from all stations issuing broadcast seismological messages were picked up by the Air Ministry and communicated to Kew Observatory. An eaxly knowledge of the position of the epicentre and of the time of origin was thus obtained. The following table summarises the in. formation received at $\mathrm{Kew}$ :

\begin{tabular}{|c|c|c|c|c|c|}
\hline Station. & $\begin{array}{c}\text { Arrival } \\
\text { of } P \\
\text { G.M.'. }\end{array}$ & $\begin{array}{c}\text { Interval } \\
\left(S^{t}-P\right)\end{array}$ & $\begin{array}{c}\text { Distance } \\
\text { of } \\
\text { Epicentre } \\
\triangle\end{array}$ & $\begin{array}{l}\text { Azimuth of } \\
\text { Epicentre } \\
\text { (from N. } \\
\text { through E). }\end{array}$ & $\begin{array}{c}\text { Time of } \\
\text { origin de- } \\
\text { duced from } \\
(S-P) \text { using } \\
\text { B.A. tables. }\end{array}$ \\
\hline $\begin{array}{l}\text { Kew } \\
\text { Helwan } \\
\text { Bombay } \\
\text { Stonyhurst, } \\
\text { Georgetown } \\
\text { Honolulu } \\
\text { Strasbourg }\end{array}$ & $\begin{array}{llll}\text { h. } & \text { n. } & \text { s. } \\
0 & 14 & 49 \\
0 & 15 & 41 \\
0 & 14 & 12 \\
0 & 14 & 39 \\
0 & 15 & 14 \\
0 & 11 & 32 \\
0 & 14 & 54\end{array}$ & $\begin{array}{rr}\mathrm{m} . & \mathrm{s} . \\
9 & 34 \\
10 & 9 \\
9 & 0 \\
9 & 21 \\
9 & 51 \\
6 & 50 \\
9 & 39\end{array}$ & $\begin{array}{l}\text { Km. } \\
8290 \\
8970 \\
7600 \\
7850 \\
8620 \\
5150 \\
8380\end{array}$ & $\begin{array}{c}19^{\circ} \\
\ldots \\
\ldots \\
330^{\circ} \pm 5^{\circ} \\
330^{\circ} \pm 5^{\circ} \\
\ldots\end{array}$ & $\begin{array}{rrr}\text { h. } & \text { m. } & \text { s. } \\
0 & 3 & 4 \\
0 & 3 & 17 \\
0 & 3 & 5 \\
0 & 3 & 8 \\
0 & 3 & 9 \\
0 & 2 & 50 \\
0 & 3 & 3\end{array}$ \\
\hline
\end{tabular}

1 The Stonyhurst figures were not broadcast, but were received by post.

The agreement between the figures in the last column is satisfactory, and for a preliminary value of the time of origin we may accept 0 h. 3 m. 6 s. G.M.T.

The accompanying diagram (Fig. 1) is taken from

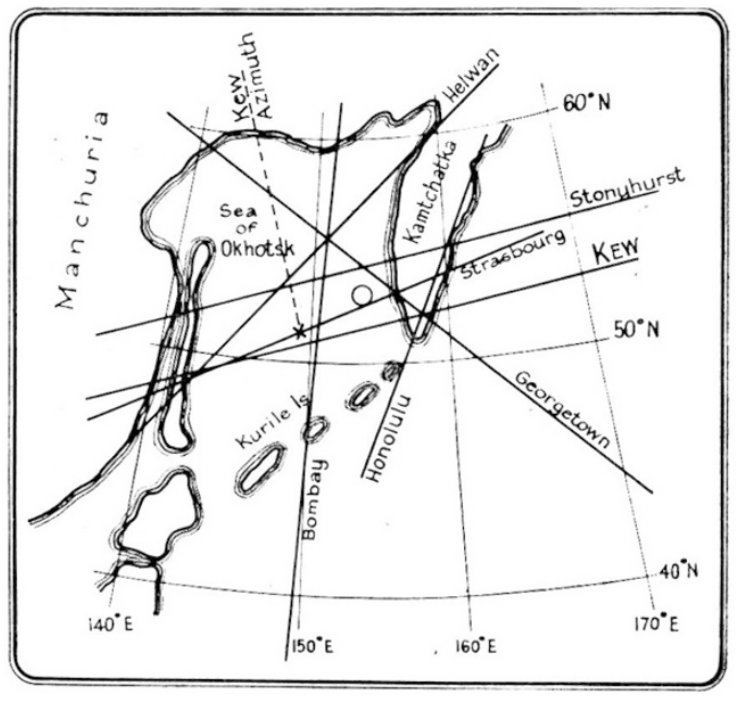

FIG. 1.

the globe on which the epicentral distances were marked off; the arcs in the neighbourhood of the epicentre are shown. From the intersections the epicentre is estimated to have been approximately at the point which is marked with a circle; that is, $53^{\circ} \mathrm{N} ., 153^{\circ} \mathrm{E}$., in the Sea of Okhotsk near the western coast of Kamtchatka. The initial impulse registered by the Kew seismographs (3 components) was sufficiently large to give a trustworthy estimate of the 